Бойко I. A., аспірант *

Полтавська державна аграрна академія

\title{
МОНІТОРИНГ ФТОРУ - ОДНОГО 3 ПРІОРИТЕТНИХ ЕЛЕМЕНТІВ ПІДЗЕМНОЇ ПИТНОЇ ВОДИ ПОЛТАВСЬКОЇ ГІДРОХІМІЧНОЇ ПРОВІНЦІЇ
}

Рецензент - доктор сільськогосподарських наук, професор Г. П. Жемела

\begin{abstract}
Розглянуто закономірності розподілу й міграциї фтору та форми його знаходження в підземних водах Полтавської області. Виявлено, щуо основною причиною утворення фторвмісних вод регіону є розвантаження глибинних мінералізованих підземних вод у зонах тектонічної активізації, порушення фізико-хімічної рівноваги природної систе-

ми та фторвміщуючі породи. Проаналізовано вплив активних форм фтору на ступінь і характер ендемічних захворювань населення та розглянуті

основні методи дефторування питної води.
\end{abstract}

Ключові слова: фтор, підземні води, міграчія фтору, мінералізація, ендемічні захворювання.

Постановка проблеми. Однією $з$ актуальних проблем екології $\epsilon$ вивчення екологогеохімічного стану природних вод і визначення можливості їх використання в питних цілях.

Особливе значення має вивчення фтору як одного 3 найактивніших елементів Землі. Вивчення закономірностей його розповсюдження в питних водах, встановлення особливостей міграції та концентрації, визначення його біологічно активних форм - основа в плані вирішення цілої низки теоретичних і прикладних завдань. Це, перш за все, виявлення територій екологічного ризику з використання некондиційних за вмістом фтору вод, які впливають на виникнення ендемічних захворювань, розробка принципово нових технологій одержання вод із кондиційним вмістом фтору.

Встановлення активних форм фтору й визначення їх вмісту досить важливе для вчасного визначення зон екологічного ризику та розробки заходів із попередження виникнення ендемічних захворювань. Рекомендована Всесвітньою організацією охорони здоров'я концентрація фтору в питній воді - не більше 1,5 мг/дм³ нормативне значення концентрації фтору співпадає з рекомендованим ВОО3 $[2,3]$. Однак у наш час в Україні для водоспоживання широко використовують води 3 некондиційним вмістом фтору, що викликає виникнення різних ендемічних захворювань.
Аналіз останніх досліджень і публікацій, у яких започатковано розв'язання проблеми. На початку XX століття в роботах видатних геохіміків В. І. Вернадського, А. П. Виноградова, В. М. Гольдшмідта, Ф. В. Кларка, А. Е. Ферсмана наводилося перші дані про вміст фтору в земній корі. Досить важливі результати досліджень із геохімії фтору зустрічаємо в працях Т. Ф. Барта, А. В. Козакова, К. У. Корренса, О. І. Соколової та інших дослідників. Особлива увага було надавалася вивченню зв'язку закономірностей розподілу фтору в природних об'єктах з ендемічними захворюваннями (флюорозом і карієсом). Цей напрям розвинуто у працях Р. Д. Габовича, О. М. Заславської, Е. В. Козлова, В. П. Комарова, С. Р. Крайнова, С. В. Моісєєва, Н. Г. Петрова, С. Н. Черкинського та ін. Вивчаючи мінеральний склад підземних вод, Р. Д. Габович та С. Р. Крайнов вперше звернули увагу на зв'язок між вмістом у водах кальцію, магнію і фтору [6]. Основні закономірності розподілу фтору в об'єктах довкілля, умови його міграції й інтеграції, а також загальні питання геохімії фтору та ендемічного захворювання розглянуто в роботах Е. Я. Жовинського [3].

Мета досліджень: проаналізувати закономірності розподілу і міграції фтору та його сполук у підземних водах Полтавської області; виявити райони 3 некондиційним вмістом фтору та оцінити стан здоров'я населення цих місцевостей щодо ендемічних захворювань.

Матеріали і методи досліджень. Вміст фору у питній води підземних джерел оцінювався за даними моніторингу Полтавської обласної санітарно-епідеміологічної станції статистичним та аналітичним методами.

Результати досліджень. Територія Полтавської області належить до Дніпровського артезіанського басейну. Найбільше практичне значення мають прісні води палеогенових (бучакськоканівських) відкладень. Глибина залягання

* Керівник-доктор сільськогосподарських наук, професор П. В. Писаренко 
водоносного горизонту залежно від рельєфу поверхні та структурних особливостей території змінюється від 5-25 до 40-60 м, іноді збільшується до 80-90 м, а в районі м. Полтави - до 125150 метрів. Водовмісні породи представлені зеленими і сірувато-зеленими середньозернистими кварц-глауконітовими пісками 3 фосфоритовими включеннями у верхній частині пісків бучакського ярусу, що чергуються 3 прошарками глин, рідше - пісковиків. Потужність водоміщуючої товщі змінюється від 20-30 до 80 метрів. Продуктивність свердловин у центральній частині району становить 5-8 м³/год, іноді збільшується до 11,81-12,4 м³/год. На території Полтавської області найчастіше зустрічаються гідрокарбонатно-натрієво-магнієві води 3 мінералізацією 0,41,0 г/л та хлоридно-кальцієво-натрієві води 3 мінералізацією 1,5-3,0 г/л (міста Полтава, Глобино, Лубни, Хорол, Лохвиця та ін.), локально розвинуті сульфатно-натрієві води з мінералізацією 1,0-1,5 г/л у Машівському районі. Хімічний склад вод бучакського горизонту змінюється в широких межах, проте завжди фіксується невисокий вміст кальцію і магнію та значна кількість хлоридів, що типово для лужних, хлориднонатрієвих вод [1].

Встановлено, що фтор $є$ елементом-індикатором тектонічних порушень. Найвищий вміст фтору властивий зонам тектонічних порушень i активізації, де створюються локальні ділянки областей зниженого тиску - найсприятливіші умови для виносу з глибин фтору водами різного походження. Біогеохімічна активність фтороносних вод, зокрема в районах тектонічних порушень, вплив їх на здоров'я людини залежать від фізикохімічних особливостей природних вод i стану фтору в цих водах. Ступінь і характер ендемічної захворюваності залежить від вмісту в питній воді активних форм фтору [3].

Формування фтороносних вод на території Полтавської області обумовлюється в значній мірі «метаморфізацією» хімічного складу підземних вод [3]. Так, у районі газових і нафтових родовищ, які знаходяться на захід від м. Миргорода, води хлоридно-кальцієвого типу характеризуються високою мінералізацією (2,5 г/л) та вмістом фтору до 4 мг/л; для соляних родовищ виявлено розсоли хлоридно-натрієвого складу зі вмістом фтору близько 8,8 мг/л. В останньому випадку збільшення вмісту фтору обумовлено надходженням фтороносних вод у зонах тектонічних порушень. Такий самий характер має закономірність розподілу фтору на захід від м. Миргорода та м. Хоролу, де проходить меридіональний розлом, уздовж якого локально виділяються ділянки 3 вмістом фтору у воді (3,65,0 мг/л) [1]. За результатами досліджень складено карту еколого-геохімічного ризику території Полтавської області, на якій виділено ділянки 3 некондиційним вмістом фтору у підземних питних водах (рис. 1). У цілому всю територію області умовно можна віднести до фтороносної гідрохімічної провінції.

Хлоридно-натрієві підземні води, поширені на території Полтавщини, мають таку особливість: при збільшенні вмісту натрію (до 600 мг/л) i хлору (до 280 мг/л) збільшується вміст фтору до 3 мг/л (за наявності тектонічних порушень - до 7 мг/л), проте в наявності кальцію вміст фтору у водах знижується. Води даного типу на досліджуваній території формуються в межах соленосних пластів, основним компонентом яких є галіт. Води цього типу характеризуються високим вмістом фтору (до 6 мг/л), у зонах тектонічних порушень - до 9 мг/л [3].

Результати аналітичних досліджень дали можливість встановити, що провідною формою міграції фтору для всіх типів вод є фторид-іон, що характерно для вод із високим вмістом іонних форм хлору та натрію. Для вод із підвищеним вмістом гідрокарбонату, сульфату й кальцію спостерігається зменшення фторид-іону і збільшення фторидів магнію та кальцію [5].

Одним 3 основних факторів, який визначає біологічну активність фтору, є форми його знаходження в природних розчинах. Утворення різних сполук фтору в значній мірі залежить від хімічного стану підземних вод, їх мінералізації, кислотно-лужних й окисювально-відновлювальних умов, а також стану водовмісних порід. Усе це зумовлює особливості їх потрапляння в організм людини й, відповідно, рівень ендемічної захворюваності [6]. Характерно, що при потраплянні фтору 3 питною водою в організмі його затримується на 15-27 \% більше, ніж за його потрапляння 3 їжею. Тому вміст активних форм фтору у водах зумовлює виникнення флюорозу (понад 1,5 мг/л) або карієсу (близько 0,7 мг/л). Захворювання зубів, що отримало назву «плямиста емаль» (флюороз), в умовах помірного клімату 3'являється навіть за вмісту фтору в питній воді дещо більше 1 мг/л. Вивчення ендемічного флюорозу проводиться по різних напрямах, зокрема, виявлення територій розвитку патогенезу i визначення клінічної картини - ступеню розвитку флюорозу [6, 7]. 


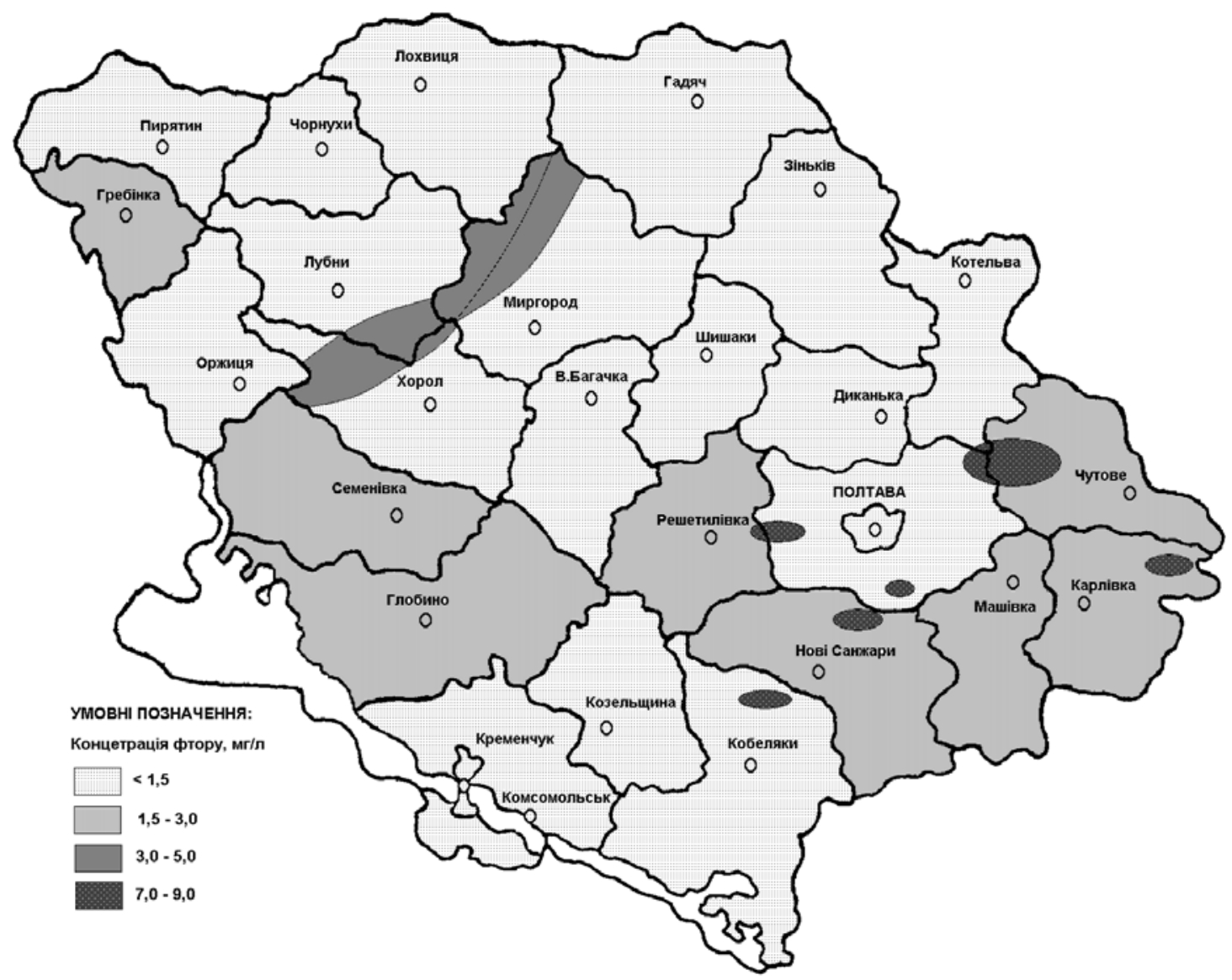

Рис. 1. Вміст фтору в підземних водах Полтавської області

У населення територій із підвищеним вмістом фтору в питних водах спостерігається флюороз зубів (90 \%), захворювання кісток, м'язів. Окрім цього, уражаються зубна та кісткова тканини, інші органи й системи організму (шлунковокишковий тракт, печінка, ендокринна система) $[6,7]$. У регіонах розвитку фтороносних вод із вмістом фтору більше 1,5 мг/л можна рекомендувати біодобавки, що перешкоджають засвоєнню фтору організмом. Це, перш за все, біодобавки та їжа 3 високим вмістом кальцію (молочні продукти) і магнію (рослинні продукти, морська капуста, вівсяна крупа, кавун). Крім того спеціалісти радять також уникати фторовмісних зубних паст [6].

У питній воді Полтавської області концентрація фтору змінюється від 0,7 до 8,8 мг/л. Згідно 3 аналізом досліджень якості питної води джерел децентралізованого водопостачання, проведених обласною Державною санітарно-епідеміологічною станцією у 2010 році, виявлено, що нормативний рівень вмісту фтору у підземних джерелах спостерігається на переважній частині Полтавської області, головним чином у півден- ній, центральній та східній частинах, менше 0,7 мг/л виявлено лише в північній частині області [4]. За усередненими результатами складено карту вмісту фтору в джерелах децентралізованого водопостачання Полтавської області (рис. 2).

У зв'язку з цим однією з актуальних проблем у використанні питних вод $\epsilon$ їх очистка від фтору. Існуючі методи дефторування води умовно поділяють на чотири групи: методи сорбції фтору осадом алюміній- або магній-гідроксиду, а також осадом кальцій фосфату; методи фільтрування води крізь фторселективні матеріали; метод електрокоагуляції, заснований на отриманні високоактивного алюміній гідроксиду шляхом електролітичного розчинення анодів, зроблених 3 алюмінію або його сплавів; метод дефторування води за допомогою зворотного осмосу.

Найчастіше у практиці водопідготовки використовуються перший і другий методи, тому що вони $є$ простими, дешевими й не порушують сольового складу води. В їх основі - хімічна взаємодія катіонів металу (алюмінію або магнію) 3 аніонами фтору та утворення стійких фторидних сполук. В якості коагулянтів частіше всього 


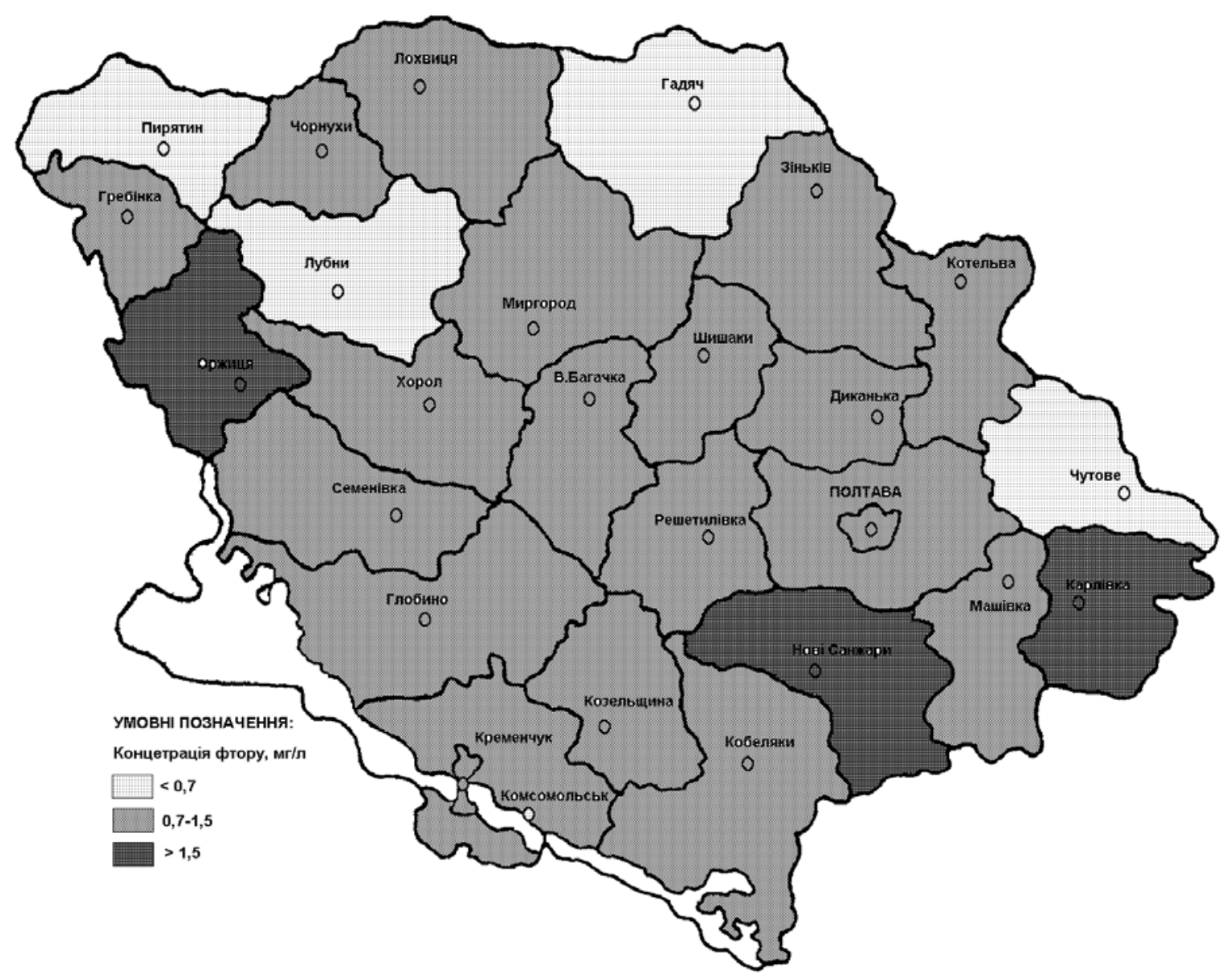

Рис. 2. Вміст фтору в децентралізованих джерелах водопостачання

використовуються алюміній сульфат та алюміній оксихлорид. Разом із чистими коагулянтами використовуються їх суміші з флокулянтами. Досить часто в якості флокулянту використовують активну силікатну кислоту. Серед методів дефторування води найперспективнішими та економічними в світі вважалися методи фільтрування води через шар активованого оксиду алюмінію. Запропоновані технологічні схеми відрізняються простотою, можливістю компактного розміщення станції при плануванні, надійністю в експлуатації. Перспективним для підземних вод вважався метод використання природних сорбентів, модифікованих солями алюмінію. Проте останнім часом доведений токсичний вплив солей алюмінію, підвищена концентрація якого виникла при використанні вказаних технологій [8].

\section{Висновки:}

1. Основними чинниками формування фтороносних вод на території Полтавської області $€$ розвантаження глибинних мінералізованих підземних вод у зонах тектонічної активізації й тектонічних порушень, геолого-структурні фактори та речовинний склад водовмісних порід. Основний водоносний горизонт (бучацький ярус) представлений пісками зі значним вмістом фосфоритових прошарків і включень, що обумовлює надходження фтору у води до 8-9 мг/л. Найвищі концентрації фтору встановлені на локальних ділянках, у зонах тектонічних порушень.

2. Досліджувана територія Полтавської області належить до так званої бучацької фтороносної гідрогеологічної провінції, підземні води якої характеризуються середнім вмістом фтору $(2,5-$ 4,5 мг/л). Це обумовлено, з одного боку, порушенням термодинамічної рівноваги між природним розчином та фосфоритовміщуючими породами верхньої частини бучакського ярусу, а 3 іншого, - розвантаженням високомінералізованих підземних вод на ділянках розвитку соляних куполів і тектонічних порушень.

3. На характер і ступінь ендемічного захворювання впливають біогеохімічно активні форми фтору, чільне місце серед яких посідає фторидіон, а також наявність інших елементів, що визначають підвищену активність фтору в питній воді. Причиною ендемічних захворювань насе- 
лення є споживання води 3 некондиційним вмістом фтору, високим вмістом натрію та низьким вмістом кальцію.

4. Керований контроль екологічного стану геологічного середовища для недопущення фторзалежного захворювання населення може грунту-

\section{БІБЛІОГРАФІЯ}

1. Бойко I. А. Загальна характеристика та особливості умов формування підземних вод на території Полтавської області як основного джерела питного водопостачання // Вісник Полтавської державної аграрної академії. - 2011. - № 2. C. $169-173$.

2. Державні санітарні норми та правила «Гігієнічні вимоги до води питної, призначеної для споживання людиною» : ДСанПіН 2.2.4-400-10. [Чинний від 2010.06.01].

3. Жовинський Е. Я., Крюченко Н. О., Дмитренко К. Е. Геохімічні критерії впливу зон тектонічних порушень на екологічну обстановку в Білорусі й Україні // Пошукова та екологічна геохімія. 2009. - № 1 (9). - C. 32-41. ватися на впровадженні технології дефторування природних вод, тому розробка принципово нової технології дефторування допоможе вирішити одну з актуальних соціально-екологічних проблем України.

4. Звіт Державної санітарно-епідеміологічної станції за 2010 рік.

5. Иванов В. В. Экологическая геохимия элементов. - М. : Наука, 1996. - Т. 3. - 352 с.

6. Крюченко Н. О. Геохімія фтору питних вод України : автореф. дис. ... канд. геол. наук спец. 04.00.02 «Геохімія» / Н. О. Крюченко. - К., 2002. $-17 \mathrm{c}$.

7. Смоляр В. И. Гипо- и гипермикроэлементозы. - К. : Здоров'я, 1989. - 150 с.

8. Щодо питання фторування і знефторення води / Ливинський О. М., Головаш Е. А., Граніч В. Н. [та ін.] // - Гігієна населених місць. - 2009. Вип. № 53. - С. 101-108. 